\title{
Larval transport processes of barnacle larvae in the vicinity of the interface between two genetically different populations of Semibalanus balanoides
}

\author{
Charles-Antoine Drouin ${ }^{1}$, Edwin Bourget ${ }^{1, *}$, Réjean Tremblay ${ }^{2}$ \\ ${ }^{1}$ Groupe interuniversitaire de recherches océanographiques du Québec (GIROQ), Département de biologie, Université \\ Laval, Ste-Foy, Québec G1K 7P4, Canada \\ ${ }^{2}$ Centre aquicole marin de Grande-Rivière (CAMGR), Ministère de l'agriculture, des pêcheries et de l'alimentation du Québec, \\ 6 du Parc, Grande-Rivière, Québec G0C 1V0, Canada
}

\begin{abstract}
Previous studies have shown a genetic interface (MPI, GPI loci) between 2 populations of the barnacle Semibalanus balanoides in the vicinity of the Miramichi Estuary, New Brunswick, in the Gulf of St. Lawrence. We examined whether gene flow between these 2 adjacent populations was restricted by larval dispersal. We determined the distribution pattern of Semibalanus balanoides planktonic larvae. Current velocity and direction, larval settlement and genetic structure of recruits were measured. Physical results and genotype distribution for MPI support the larval exchange hypothesis (north to south). The presence of another allele, GPI*4, suggests a substantial contribution of another population, possibly from the subtidal zone, to the larval pool. In accordance with previous studies, our results suggest strong selection on newly settled spat in the intertidal zone.
\end{abstract}

KEY WORDS: Larval transport $\cdot$ Semibalanus balanoides $\cdot$ MPI $\cdot$ GPI $\cdot$ Gene flow $\cdot$ Hydrodynamic structure $\cdot$ Circulation patterns

\section{INTRODUCTION}

Planktonic larvae are dispersed by a combination of currents at a variety of space and time scales. This dispersal of individuals has important population dynamic and genetic consequences (Gaines \& McClenaghan 1980, Roughgarden et al. 1988, Ebenhard 1991, Gilpin 1991). In larval dispersion models, the major processes usually considered are diffusion, advection and mortality (Okubo 1980, Possingham \& Roughgarden 1990, Hill 1991, Richards et al. 1995, Alexander \& Roughgarden 1996). Both larval behavior (Burton \& Feldman 1982) and oceanographic circulation patterns (Ketchum 1954, Ayers 1956, Hedgecock 1986, Mitton et al. 1989) may limit dispersal and thus

\footnotetext{
${ }^{*}$ Corresponding author. Present address: Vice-recteur à la recherche, Université de Sherbrooke, Sherbrooke J1K 2R1, Canada. E-mail: edwin.bourget@rectorat.usherb.ca
}

influence genetic differentiation (Bertness \& Gaines 1993). Outside estuaries (see Bousfield 1955, Epifanio et al. 1984, 1989, Epifiano 1988a,b, Dame \& Allen 1996), larval transport is poorly understood (LeFèvre \& Bourget 1992) and despite the fact that coastal circulation is known to vary, the influence of oceanographic transport has received little consideration (Bertness \& Gaines 1993).

Given the potential for long-range dispersal of planktotrophic larvae, it is not surprising that many studies have found large scale genetic homogeneity for such species (Berger 1973, Gooch et al. 1973, Janson \& Ward 1984, Johnson \& Black 1984, Hoagland 1985, Holborn et al. 1994). However, there is also evidence for differentiation of local populations in species with a planktonic larval stage (Hedgecock 1986).

The cirripede Semibalanus balanoides is the dominant intertidal barnacle in circumboreal waters. Its life cycle includes 7 different larval stages, 6 nauplii and 1 cypris (Bassindale 1936). In North America, it is pre- 
sent in the North Atlantic, from Baffin Island to Cape Hatteras (Wells et al. 1960, Barnes \& Barnes 1976). Crisp (1964), Barnes (1965), Barnes \& Barnes (1976) and Flowerdew $(1983 a, b)$ presented evidence for racial differences among American and European populations, and Holm \& Bourget (1994) confirmed these variations, though they showed that regional variations were often larger than trans-Atlantic differences. Bourget et al. (1989) have shown that behavioral, morphological and genetic differences occur between the Gulf of St. Lawrence and North Atlantic populations of Semibalanus balanoides. The 2 populations had different allele frequency for 2 allozymes, MPI (mannose-6phosphate isomerase) and GPI (glucose-6-phosphate isomerase). Holm \& Bourget (1994) have subsequently described the genetic characteristics of 11 populations from different sites within the Gulf of St. Lawrence and found a discontinuity in allele frequency, for the same 2 loci $\left(M P I^{*}\right.$ and $\left.G P I^{*}\right)$ in the vicinity of the Miramichi Estuary, New Brunswick. The population north of the Miramichi Estuary is characterized by low GPI*3 and $M P I^{*} 2$ frequencies while the population south of the Miramichi Estuary is characterized by relatively high frequencies for these 2 allozymes.

In our study, we determined if gene flow between those 2 adjacent populations was restricted by larval dispersal. We sampled plankton to determine the dispersal pattern of Semibalanus balanoides larvae in the interface region over the dispersal period. In large scale dispersal studies, larval abundance needs to be

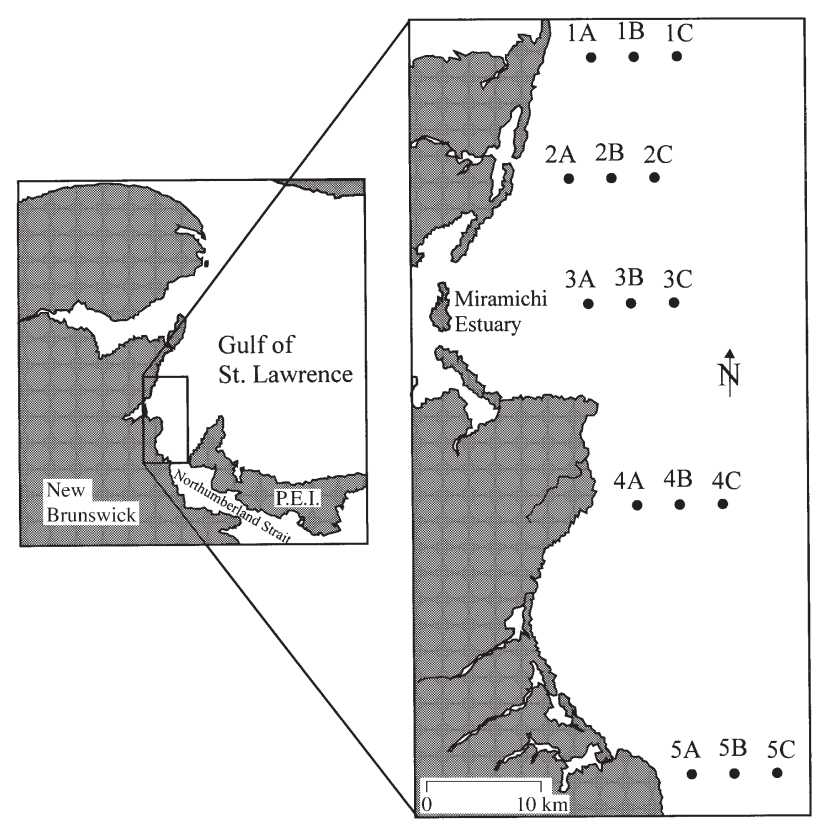

Fig. 1. Map of the study area situated in the southern Gulf of St. Lawrence and position of sampling stations near the mouth of the Miramichi Estuary examined as a function of hydrodynamics (Gaines \& Bertness 1993) and other physico-chemical processes both in time and space. Therefore, current velocity and direction, water salinity and temperature were also measured. Finally, we determined whether larval distribution corresponded to larval settlement by deploying settlement collectors and characterizing the genetic structure of recruits settled onto the collectors.

\section{MATERIALS AND METHODS}

Study area. The study area was situated in the southwestern Gulf of St. Lawrence, in the vicinity of the Miramichi Estuary, New Brunswick (Fig. 1). In this region, Lauzier (1965) described a cyclonic eddy in the northern entrance of the Northumberland Strait with a southerly drift along the New Brunswick coast and a northeasterly drift along the Prince Edward Island coast. Using a model, Trites \& Drinkwater (1991) suggested an offshore transport of surface waters along the northeast coast of New Brunswick, under normal winds. The predictions agreed with the upwelling proposed by Lauzier (1967), although we suspect the model itself may have been strongly influenced by Lauzier's initial suggestion of a gyre in this region.

Mean sea surface salinity for the spring is about 28 to $30 \%$ and mean surface temperature reaches up to $12^{\circ} \mathrm{C}$ (Petrie 1990). The Miramichi Estuary is one of the largest estuaries in Atlantic Canada (surface area $300 \mathrm{~km}^{2}$; drainage basin area $\sim 14000 \mathrm{~km}^{2}$ ) (Locke \& Courtenay 1996). At its mouth, it is about $20 \mathrm{~km}$ long and $20 \mathrm{~km}$ wide. The average annual flow at the mouth of the river is approximately $250 \mathrm{~m}^{3} \mathrm{~s}^{-1}$, but daily peaks of $6300 \mathrm{~m}^{3} \mathrm{~s}^{-1}$ can be reached during the spring freshet (Lavoie 1995). Predicted tidal amplitude for that region ranged from 0.1 to $1.4 \mathrm{~m}$ during the study period (Canadian Hydrographic Service 1998).

Larval sampling. Plankton samples were collected at 15 offshore stations located in the Gulf of St. Lawrence near the mouth of the Miramichi Estuary. The area covered by the stations $(\sim 10 \times 100 \mathrm{~km})$ was approximately $1000 \mathrm{~km}^{2}$. The grid of sampling stations consisted of 5 transects of 3 stations perpendicular to the coast (Fig. 1). Stations were located at a distance of 2, 6 and $10 \mathrm{~km}$ from the coast. The latter corresponding to the maximum offshore distance Semibalanus balanoides larvae have been observed in other studies (Lefèvre \& Bourget 1991). Two sections were located north of the Miramichi Estuary, a middle one in front of the mouth of the estuary and two to the south (Fig. 1). All stations $(n=15)$ were sampled on a weekly basis from 4 May to 2 July 1998. Sampling all the stations took 2 to $3 \mathrm{~d}$, depending on weather conditions. Sampling was conducted regardless of the tidal stage and 
took place during daytime between 6:00 and 18:00 h. Local variability in larval density was estimated by using 2 samples (Omori \& Hamner 1982) at each station throughout sampling. Samples were preserved in $4 \%$ formaldehyde in filtered seawater for later identification and enumeration.

We used a $150 \mu \mathrm{m}$ plankton net of $0.25 \mathrm{~m}$ radius, as the first stage of Semibalanus balanoides larvae have a minimum size of about $220 \mu \mathrm{m}$ (Bassindale 1936). The early nauplii stages of $S$. balanoides are located mainly near the surface, the later stages in midwater, while cypris larvae are mostly suprabenthic (Bousfield 1955, Gaines \& Bertness 1993, Miron et al. 1995), so sampling integrated the whole water column. We sampled horizontally for $1 \mathrm{~min}$ close to the surface, obliquely for $30 \mathrm{~s}$ from the surface down to the bottom, horizontally $1 \mathrm{~min}$ near $(\sim 1 \mathrm{~m})$ the bottom and finally $30 \mathrm{~s}$ obliquely from the bottom back to the surface, at throttle speed $\left(\sim 2.5 \mathrm{~km} \mathrm{~h}^{-1}\right)$. Because the sampling design integrates larvae over the whole water column, the likelihood of capturing all larval stages was the same at each station. Station depths varied between 6.8 and $25 \mathrm{~m}$. For each sample, a calibrated flowmeter (General Oceanics, Model 2030) was attached at the mouth of the net to measure the quantity of water filtered. An average of $24.3 \mathrm{~m}^{3}$ of seawater was filtered per tow.

Recruitment. At the 2 northern and the 2 southern sections close to the shore (Stns 1A, 2A, 4A and 5A), 9 grey Arborite ${ }^{\circledR}$ panels $(10 \times 30 \times 0.1 \mathrm{~cm}$; the rough surface of the back of panels were used as collectors) were moored vertically on 3 lines, $50 \mathrm{~m}$ apart, each supporting 3 panels which automatically oriented parallel to the water current direction. The panels were at $0.70,0.90$ and $1.10 \mathrm{~m}$ from the bottom. They were moored on 5 and 6 May 1998. At that period, no cypris larvae were present in the water column. The panels were retrieved on 3 June and settled barnacles were frozen at $-80^{\circ} \mathrm{C}$ for genetic analysis.

Environmental data. At the $6 \mathrm{~km}$ station of each transect (Stns 1B, 2B, 3B, 4B and 5B), a currentmeter (Aanderaa, Model RCM 4, InterOcean) was moored at $1 \mathrm{~m}$ from the bottom. At Stn 3B, an additional currentmeter was also moored at $6 \mathrm{~m}$ from the surface. Current velocity $\left( \pm 1 \mathrm{~cm} \mathrm{~s}^{-1}\right)$, direction $\left( \pm 1^{\circ}\right)$, seawater temperature $\left( \pm 0.15^{\circ} \mathrm{C}\right)$ and salinity (conductivity, $\pm 0.03 \mathrm{mmho} \mathrm{s}^{-1}$ ) were monitored. All physical data were recorded every $15 \mathrm{~min}$ throughout the sampling period, from 25 to 28 April to between 1 and 2 June 1998. Also, on each visit at each station, a salinitytemperature profile using a CTD (Sea Bird Electronics, Sea Cat Profiler, Model SBE 19) was made in order to determine the degree and depth of stratification of the water column.

Laboratory procedures. Semibalanus balanoides larvae were identified to the larval stage according to
Bassindale (1936), Pyefinch (1948) and Crisp (1962). A bulb pipette method was used for subsampling. Samples were diluted to $200 \mathrm{ml}$, stirred until approximately homogeneous, and subsampled (with $5 \mathrm{ml}$ aliquots) until either 300 S. balanoides larvae were obtained or $25 \%$ of the total sample volume had been subsampled (Van Guelphen et al. 1982). Results are expressed as number of larvae $\mathrm{m}^{-3}$ for analysis, and stages were grouped as nauplii (stages 1 to 3), metanauplii (stages 4 to 6 ) and cyprids.

Genetic analysis. Somatic tissues of each recruit collected on panels were homogenized in $50 \mu \mathrm{l}$ of homogenization buffer $(0.2 \mathrm{M}$ Tris- $\mathrm{HCl} \mathrm{pH} 8.0$, with $30 \%$ sucrose, $1 \%$ polyvinylpolypyrrolidone, $0.1 \%$ Nicotinamide Adenine Dinucleotide [NAD], $5 \mathrm{mM}$ dithiothreitol, and $1 \mathrm{mM}$ 4-[2-aminoethyl]-benzenesulfonyl fluoride hydrocholoride [Pefabloc Sc, Boehringer Mannheim]). The solution was applied to a horizontal cellulose acetate gel (Hebert \& Beaton 1989). The polymorphic enzymes examined were glucose phosphate isomerase (GPI EC 5.3.1.9) and mannose phosphate isomerase (MPI EC 5.3.1.8). These have been shown to exhibit substantial variability and have been studied in the adult populations in the study area (Holm \& Bourget 1994). A 'standard' was prepared by mixing homogenates of individuals of different genotypes. This 'standard' of all possible alleles for a given locus was applied on each gel to ensure exact allele identification. The gene nomenclature for protein-coding loci follows the recommendations of Shaklee et al. (1990).

Data analysis. Larval densities of different stages of Semibalanus balanoides through time and space were used to determine dispersal patterns. Allele frequencies, observed and expected heterozygosities under the assumption of Hardy-Weinberg equilibrium and heterozygote deficiency index $(D)$, were calculated for each locus using the BIOSYS-1 program of Swofford \& Selander (1989). Results in allele frequencies were compared with published results in adults (Holm \& Bourget 1994) to determine the origin of recruits ('northern' or 'southern' populations; see 'Introduction').

\section{RESULTS}

\section{Current, salinity and temperature}

Mean current velocity averaged between 0.2 and $3.4 \mathrm{~cm} \mathrm{~s}^{-1}$ for all the transects over the $30 \mathrm{~d}$ of immersion. At Stn $4 B$, current was predominantly northeast while, at Stn $5 B$, the northwest direction predominated (Fig. 2). This hydrodynamic structure was stable over the sampling period and suggests an anticyclonic eddy at the northern end of the Northumberland Strait. 


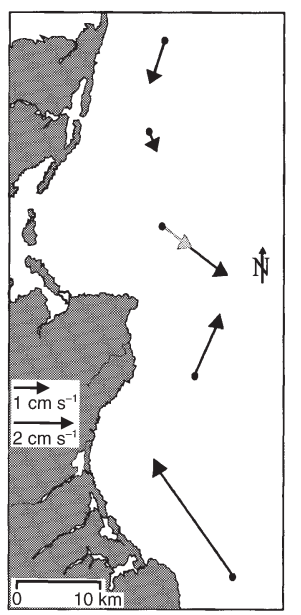

A.

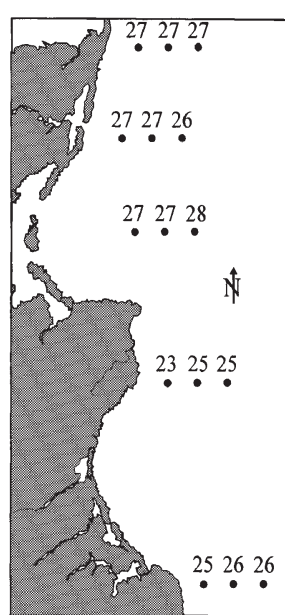

B.

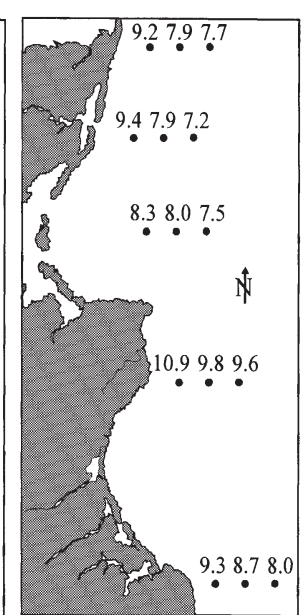

C.

Fig. 2. (A) Mean current velocities and directions. Black arrows represent current vectors close to the bottom and gray arrow current vectors at $6 \mathrm{~m}$ from the surface. As will be seen from the figure, bottom and surface current directions were parallel. (B) Mean sea surface salinities $(\%)$ and $(\mathrm{C})$ mean sea surface temperatures $\left({ }^{\circ} \mathrm{C}\right)$ from CTD casts in the southern Gulf of St. Lawrence near the mouth of the Miramichi Estuary, between 4 May and 2 July 1998. See Fig. 1 for station identification

From the northern end of the sampling grid the transect closer to the mouth of the Miramichi Estuary, currents were predominantly southward. Mean surface salinities averaged between 23 and $28 \%$ and were lowest at Stn $4 \mathrm{~A}$, the station closest to the coast south of the Miramichi Estuary (Fig. 2). Mean surface temperatures averaged between 7.2 and $10.9^{\circ} \mathrm{C}$ and in general were higher at stations on the southern transects sampled (Fig. 2).

\section{Larval sampling}

In general, we observed very low larval densities at most of the stations through time (Fig. 3). Along the 2 northern transects ( 1 and 2), we observed a considerable number of larvae only at the 2 stations close to the shore for the first sampling date (138.7 and 49.6 larvae $\mathrm{m}^{-3}$ for Stns 1A and 2A, respectively). Otherwise, larval densities were always $<10$ larvae $\mathrm{m}^{-3}$. Along the transect at the mouth of the Miramichi Estuary, densities were always $<1$ larvae $\mathrm{m}^{-3}$ except for the first sampling date when they reached 28.2, 28.6 and 20.7 larvae $\mathrm{m}^{-3}$ for Stns 3A, B and C, respectively. On all of these 3 transects, cypris larvae never reached densities $>0.8$ larvae $\mathrm{m}^{-3}$, and most of the time none were observed.

On the transects south of the mouth of the Miramichi Estuary, larval densities were always higher than on the northern transects. This north-south asymmetry in

larval densities was especially evident for cyprids. Along Transect 4, highest larval densities for all stations were observed on the 2 first sampling dates. Few cyprids were observed at Stn $4 \mathrm{~A}$ on the second week of sampling (9.6 cyprids $\mathrm{m}^{-3}$ ), and after, very low larval densities were observed ( 7.9 to 0.4 larvae $\mathrm{m}^{-3}$ ), except on the last sampling date at Stn $4 \mathrm{~A}$. Transect 5 was the only one in which substantial numbers of cyprids were found, reaching 87.1 cyprids $\mathrm{m}^{-3}$ at $\mathrm{Stn} 5 \mathrm{C}$ in wk 3 of sampling. Finally, on the last week of sampling, we observed a second pulse of early nauplii at Stns $4 \mathrm{~A}$ and $5 \mathrm{~A}$, suggesting a second spawning period.

\section{Recruitment}

Probably due to the intense lobster fishing in the area, 2 of the settlement structures were lost (Transects 2 and 4). At Stn 1, no larvae or spat were observed on any of the 9 arborite panels. At Stn 5, we observed a total of 48 recruits $\left(177\right.$ recruits $\left.\mathrm{m}^{-2}\right)$. These recruits had a mean rostro-carinal diameter of $1.67 \mathrm{~mm}( \pm$ $0.22 \mathrm{~mm}, \mathrm{n}=13$ ) which corresponds to an age of 1 to 2 wk (Bourget et al. 1989). Recruitment on current-

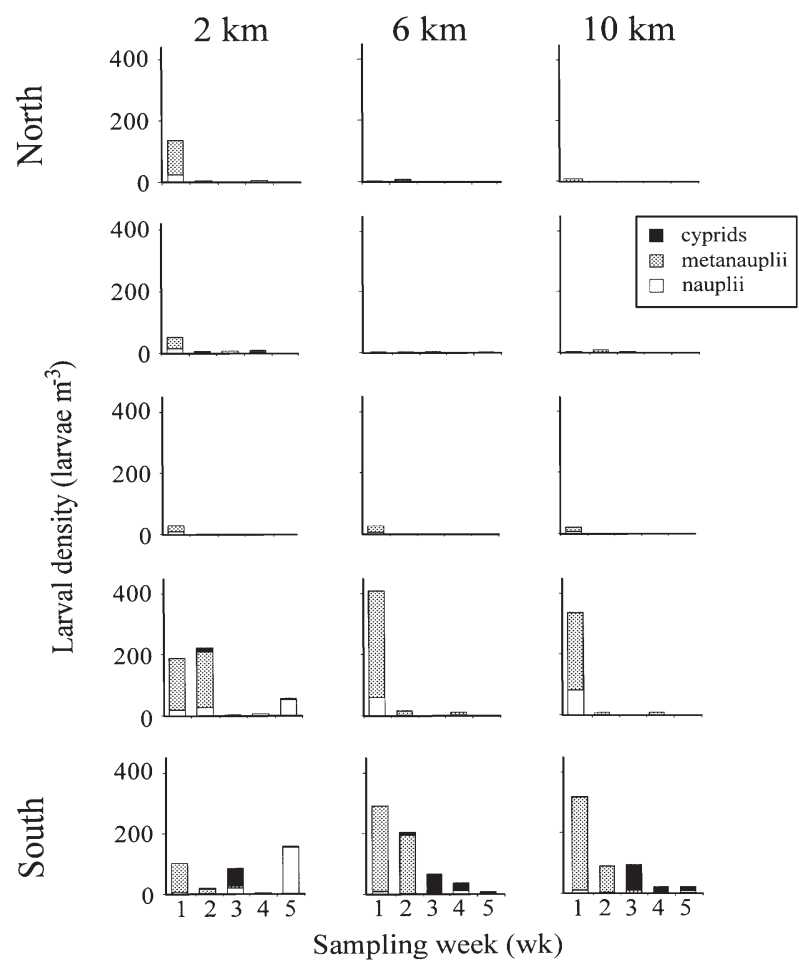

Fig. 3. Semibalanus balanoides. Density of planktonic larvae (larvae $\mathrm{m}^{-3}$ ) for each sampling week (first, 4 May; last, 2 June 1998) near the mouth of the Miramichi Estuary, in the southern Gulf of St. Lawrence. Columns represent distances offshore and rows represent transects, from north to south (see Fig. 1) 
Table 1. Semibalanus balanoides. Allelic frequencies for MPI and GPI for barnacles recruited onto panels (approx. 2 wk old). Lines 1 and 2 are results from Holm \& Bourget (1994) for the same region. Line 4 represents the allele frequencies after we applied artificial selection of $100 \%$ against GPI*4

\begin{tabular}{|c|c|c|c|c|c|c|c|c|}
\hline Source & $\mathrm{n}$ & $M P I^{*} 1$ & $M P I^{*} 2$ & $M P I^{*} 3$ & $\mathrm{n}$ & $G P I^{*} 2$ & $G P I^{*} 3$ & $G P I^{*} 4$ \\
\hline North 1992 & 92 & 0.01 & 0.27 & 0.72 & 94 & 0.69 & 0.31 & 0.00 \\
\hline South 1992 & 91 & 0.00 & 0.48 & 0.52 & 94 & 0.55 & 0.45 & 0.00 \\
\hline Recruits 1998 & 46 & 0.03 & 0.36 & 0.61 & 48 & 0.53 & 0.24 & 0.23 \\
\hline After selection on $G P I^{*} 4$ & 28 & 0.02 & 0.38 & 0.61 & 28 & 0.71 & 0.29 & 0.00 \\
\hline
\end{tabular}

meters moored at the middle stations of each transects reflected the above pattern since the currentmeter moored at Stn 5B was the only one to recruit barnacles.

\section{Genetic analysis}

We observed, for the $M P I^{*}$ locus, 1 rare and 2 common alleles, labeled as 1, 2 and 3, based on their distance from the origin on the gel. For the GPI* locus, 3 common alleles were found. They were labeled as 2, 3 and 4 as we did not find the rare allele 1 identified previously (Holm \& Bourget 1994). Allelic frequencies on recruits are presented in Table 1 along with Holm \& Bourget's (1994) results on adults for the closest north and south sampling stations. For GPI, we observed a third common allele, GPI*4. In Holm \& Bourget (1994), this allele occurred only in newly settled individuals and at a very low frequency (0.019). Since this allele has never been reported on adults along the coast, we assumed strong selection against GPI*4. As a modeling exercise, we therefore applied artificial selection of $100 \%$ against $G P I^{*} 4$ by excluding from analysis all individuals with this allele, and examined the other loci. Selection pressure did not affect allelic frequency for $M P I^{*}$, but for the $G P I^{*}$ results were somewhat at odds with the expected values. Thus recruits had GPI* frequencies comparable to the frequencies of the south population, and $M P I^{*}$ frequencies intermediate between the north and south, which suggest recruitment from the 2 different populations. For $M P I^{*}$, the proportion of observed heterozygotes $\left(H_{0}\right)$ were generally in a good agreement with values expected $\left(H_{\mathrm{e}}\right)$ under Hardy-Weinberg equilibrum before $(D=-0.096, \mathrm{p}=$ $0.505)$ and after selection $(D=-0.070, \mathrm{p}=0.623)$. For $G P I^{*}$, we observed a significant deficit of heterozygosity both before $(D=-0.186, \mathrm{p}=0.038)$ and after selection $(D=-0.484, \mathrm{p}=0.008)$.

\section{DISCUSSION}

Our study examines whether larval exchange occurs between Gulf populations of Semibalanus balanoides north and south of the Miramichi Estuary. Current directions suggested a north to south larval exchange. This hypothesis is also supported by larval distribution and genetic analysis.

\section{Hydrodynamic structures}

In the northern part of the study area, currents had a predominantly southward orientation. This pattern would favor unidirectional transport of larvae from the northern region to the southern region.

The orientation and stability of currents south of the Miramichi Estuary suggest the presence of an anticyclonic gyre at the entrance of the Northumberland Strait. Lauzier (1965) described a cyclonic gyre in the same region, but his results were based on drift bottles releases from fixed stations in the Strait and recoveries along the coast. The inferred circulation of the surface waters in the Northumberland Strait (as presented by Lauzier 1965) should be taken with care as the bottles may indicate surface circulation patterns under various weather conditions, a fact recognized by Lauzier (1965). Here, our results are based on in situ recordings of current directions and velocities over a long period. We observed higher surface temperature at the mouth of Northumberland Strait, which are also typical of an anticyclonic gyre.

Lower salinity observed at Stn 4A suggests that freshet from the Miramichi Estuary might flow south along the coast instead of directly offshore in the Gulf St. Lawrence.

\section{Larval transport processes and recruitment}

Larval densities are affected by the reproductive output of adults (Barnes 1956, 1962, Connell 1961, Geraci \& Romairone 1982). In our study, low larval densities were observed through time. This is not too surprising since there is a lack of hard substrate available for colonization and consequently few adults are present, as a result therefore, a low number of larvae are spawned. An analogous situation was observed in 
Portugal where the long sandy coast south of São Martinho do Porto proves a geographical barrier to marginal dispersion and thus limits the southern distribution of the barnacle Elminius modestus (Barnes \& Barnes 1965).

The presence of larvae during the first sampling week on Transect 3, their disappearance from this and northern transects after, and their increase on southern transects with time suggests a north-south larval drift. Local current directions also support this hypothesis. High larval densities observed on southern transects suggest that larvae coming from the north are mixed with those originating from the south. The gyre occurring south of the Miramichi Estuary may cause larval retention and could help explain those higher densities observed in this region. In the past, gyres have often been associated with larval retention (Johnson 1960, 1971a,b, Knudsen 1960, Efford 1970, Alldredge \& Hamner 1980, Kendall et al. 1982, Nichols et al. 1982, Yoshioka 1986).

For cypris, the observed densities were very low everywhere, but were found in greatest numbers along Transect 5, the only one where recruitment was observed on collectors (Stn 5A) and on current meters (Stn 5B).

\section{Genetic origin of spat and selection on $\operatorname{GPI}^{*} 4$}

Genetic results obtained from the analysis of recruits at Stn 5A seem to support the hypothesis of larval mixing, as does larval densities and current analysis. For $M P I^{*} 2$, we observed an allele frequency intermediate between that observed in populations from the northern and southern Gulf of St. Lawrence (Holm \& Bourget 1994) suggesting that larvae from both populations settled on our panels. The same results were obtained by Holm \& Bourget (1994) with recruits from Shediac, approximately $100 \mathrm{~km}$ south of the Miramichi Estuary. However, the allelic frequency of $G P I^{*} 2$ would suggest that recruits on panels originate mainly from the southern population. For GPI* locus, the presence of a third relatively frequent allele (GPI*4, frequency of 0.23$)$ is intriguing. This third allele was also observed by Holm \& Bourget (1994) in recruits from Port Elgin (0.019) and Pictou (0.009), both situated south of Miramichi Estuary in the Northumberland Strait and was considered as a rare allele then. This allele was never observed in adults. In our study, GPI* 4 was not a rare allele. The recruits were obtained from panels which were continuously immersed. All other genetic analyses on Semibalanus balanoides in this region were obtained from adults or recruits sampled in the intertidal zone, thus exposed to emersion during low tides. Glucose-6-phosphate isomerase (GPI) is a catalyzing enzyme in the interconversion of glucose-6-phosphate and fructose-6-phosphate in glucolysis and gluconeogenesis. The kinetic properties of different allele forms of GPI* are well known to vary with temperature (Hoffmann 1981a, Hall 1985, Van Beneden \& Powers 1989, Zamer \& Hoffmann 1989). The latter factor also appears to be an important selective factor at the GPI* locus in amphipods (Patarnello \& Battaglia 1992), mussels (Hall 1985), sea anemones (Hoffmann 1981b), and fish (Van Beneden \& Powers 1989). These results combined with those of our study suggest that temperatures experienced during emersion may be involved in the selection process. However, Schmidt \& Rand (1999) found that GPI was neutral among thermal microhabitats for $S$. balanoides.

The $G P I^{*} 4$ allele has never been found in adults of the intertidal. It is thus possible that selective pressure is exerted against that specific allele. Recruits studied by Holm \& Bourget (1994) were collected about a month after settlement and had very low frequencies of $G P I^{*} 4$. In our study, recruits were collected 1 to $2 \mathrm{wk}$ after settlement but were not submitted to desiccation and large temperature variations stress characteristic of the intertidal. Semibalanus balanoides is known to occur subtidally as well as tidally (Bousfield 1954, 1955, Bourget \& Lacroix 1973). We hypothesize that the GPI*4 allele will be present in a parental population that do not undergo those selective pressures from the intertidal zone, and we suggest that GPI* 4 must be frequent in barnacles from the subtidal zone. If this were the case, the former studies underestimated that recruitment source, which could explain the observed frequency of $G P I^{*} 4$ over $20 \%$.

It is not too difficult to determine what the frequency of $G P{ }^{*} 4$ would have been if those barnacles settled on panels had been recruited to the intertidal zone, and had been subjected to a selective pressure of $100 \%$ on GPI*4. The allele frequency for $G P I^{*} 2$, which corresponded to the frequencies observed in the southern population before selection, was more characteristic of the northern population after the application of selective pressure (without GPI*4). These results need to be interpreted with caution, however, since the origin of larvae may be less clear than initially thought and there may be a substantial contribution to the larval pool of larvae of unknown genetic composition, from a subtidal population.

In the light of our results, gene flow from north to south appears to occur in the area studied. Our genetic results suggest that the divergence observed in the population must be maintained through strong selection. In addition, the presence of $G P I^{*} 4$ suggests that an unknown adult source, possibly from the subtidal zone, could substantially contribute to the larval pool. Further work needs to establish (1) the contribution of subtidal barnacles to the larval pool and their importance in the larval exchange process, and (2) selective factors acting on newly settled recruits. 
Acknowledgements. We thank J.-Y. Anctil, I. Escoffier, O. Pelain and J. Bouchard-Roussin for field assistance. Special thanks are due to L. Lapointe for assistance in the laboratory. This research was support by NSERC grants (Natural Sciences and Engineering Research Council of Canada) and FCAR grants (Fonds pour la Formation de Chercheurs et l'Aide à la Recherche) to E.B. and by a scholarship from GIROQ (Groupe Interuniversitaire de Recherches Océanographiques du Québec) to C.-A. Drouin. This study is a contribution to the program of GIROQ.

\section{LITERATURE CITED}

Alexander SE, Roughgarden J (1996) Larval transport and population dynamics of intertidal barnacles: a coupled benthic/oceanic model. Ecol Monogr 66:259-275

Alldredge AL, Hamner WM (1980) Recurring aggregation of zooplankton by a tidal current. Estuar Coast Mar Sci 10: $31-34$

Ayers JC (1956) Population dynamics of the marine clam, Mya arenaria. Limnol Oceanogr 1:26-34

Barnes H (1956) Balanus balanoides in the Firth of Clyde: the development and annual variation of the larval population, and the causative factors. J Anim Ecol 25:72-84

Barnes H (1962) Notes on variations in the realease of nauplii of Balanus balanoides with special reference to the spring diatom outburst. Crustaceana 4:118-122

Barnes H (1965) Biometrical studies on some common cirripede. I. Balanus balanoides: measurements of the scuta and terga of animals from a wide geographical range. J Mar Biol Assoc UK 45:779-789

Barnes H, Barnes M (1965) Elminius modestus Darwin: further European records. Prog Oceanogr 3:23-30

Barnes H, Barnes M (1976) The rate of development of the embryos of Balanus balanoides (L.) from a number of European and American populations and the designation of local races. J Exp Mar Biol Ecol 24:251-269

Bassindale R (1936) The developmental stages of three English barnacles, Balanus balanoides (Linn.), Chthamalus stellatus (Poli), and Verruca stroemia (O. F. Müller). Proc Zool Soc Lond 1:57-74

Berger EM (1973) Gene-enzyme variation in three sympatric species of Littorina. Biol Bull 145:83-90

Bertness MD, Gaines SD (1993) Larval dispersal and local adaptation in acorn barnacles. Evolution 47:316-320

Bourget E, Lacroix G (1973) Aspects saisonniers de la fixation de l'épifaune benthique de l'étage infralittoral de l'estuaire du Saint-Laurent. J Fish Res Board Can 30:867-880

Bourget E, Martel N, Lapointe L, Bussières D (1989) Behavioural, morphological and genetic changes in some North Atlantic populations of the barnacle Semibalanus balanoides. In: Garbary DJ, South GR (eds) Evolutionary biogeography of the marine algae of the North Atlantic. NATO ASI Ser Vol. G22. Springer Verlag, Berlin, p 87-106

Bousfield EL (1954) The distribution and spawning seasons of barnacles on the Atlantic coast of Canada. Ann Rep Nat Mus 132:112-154

Bousfield EL (1955) Ecological control of the occurrence of barnacles on the Atlantic coast of Canada. Ann Rep Nat Mus 137:1-69

Burton RS, Feldman M (1982) Population genetics of coastal and estuarine invertebrates: does larval behavior influence population structure? In: Kennedy VS (ed) Estuarine comparison. Academic Press, New York, p 537-551

Canadian Hydrographic Service (1998) Canadian tide and current tables, 1998. Vol 2, Gulf of St. Lawrence. Department of Fisheries and Oceans, Ottawa

Connell JH (1961) Effects of competition, predation by Thais lapillus, and other factors on natural populations of the barnacle Balanus balanoides. Ecol Monogr 31:61-104

Crisp DJ (1962) The planktonic stages of the cirripedia Balanus balanoides (L.) and Balanus balanus (L.) from north temperate waters. Crustaceana 3:207-221

Crisp DJ (1964) Racial differences between North American and European forms of Balanus balanoides. J Mar Biol Assoc UK 44:33-45

Dame RF, Allen DM (1996) Between estuaries and the sea. J Exp Mar Biol Ecol 200:169-185

Ebenhard $\mathrm{T}$ (1991) Colonization in metapopulations-a review of theory and observations. Biol J Linn Soc 42: $105-121$

Efford IE (1970) Recruitment to sedentary marine populations as exemplified by the sand crab, Emerita analoga (Decapoda, Hippidae). Crustaceana 18:293-308

Epifiano CE (1988a) Transport of crab larvae between estuaries and the continental shelf. In: Bengt-Owe J (ed) Lecture notes on coastal and estuarine studies. Coastal-offshore ecosystem interactions, San Francisco. Springer-Verlag, Berlin, p 291-305

Epifiano CE (1988b) Transport of invertebrate larvae between estuaries and the continental shelf. Am Fish Soc Symp 3: 104-114

Epifiano CE, Masse AK, Garvine RW (1989) Transport of blue crab larvae by surface currents off Delaware Bay, USA. Mar Ecol Prog Ser 54:35-41

Epifiano CE, Valenti CC, Pembroke AE (1984) Dispersal and recruitment of blue crab larvae in Delaware Bay, USA. Estuar Coast Shelf Sci 18:1-12

Flowerdew MW (1983a) Electrophoretic investigation of population of the cirripede Balanus balanoides around the North Atlantic seaboard. Crustaceana 45:260-278

Flowerdew MW (1983b) The circumboreal barnacle Balanus balanoides (L.) and its subpopulations. In: Oxford GS, Rollinson D (eds) Protein polymorphism: adaptive and taxonomic significance. Systematics Association Spec Vol 24. Academic Press, London, p 75-84

Gaines SD, Bertness MD (1993) The dynamics of juvenile dispersal: why field ecologists must integrate. Ecology 74: 2430-2435

Gaines SD, McClenaghan LR (1980) Dispersal in small mammals. Annu Rev Ecol Syst 11:163-196

Geraci S, Romairone V (1982) Barnacle larvae and their settlement in Genoa harbour (North Tyrrhenian Sea). Mar Ecol 3:225-232

Gilpin M (1991) The genetic effective size of metapopulation. Biol J Linn Soc 42:165-175

Gooch JL, Smith BS, Knupp D (1973) Regional survey of gene frequencies in the mud snail Nassarius obsoletus. Biol Bull 142:36-48

Hall JG (1985) Temperature-related kinetic differentiation of glucosephosphate isomerase alleloenzymes isolated from the blue mussel, Mytilus edulis. Biochem Genet 23: 705-728

Hebert DPN, Beaton MJ (1989) Methodologies for allozyme analysis using cellulose acetate electrophoresis. Helena Laboratories, Beaumont, TX

Hedgecock R (1986) Is gene flow from pelagic larval dispersal important in the adaptation and evolution of marine invertebrates? Bull Mar Sci 39:550-565

Hill AE (1991) Advection-diffusion-mortality solutions for investigating pelagic larval dispersal. Mar Ecol Prog Ser 70:117-128 
Hoagland KE (1985) Generic relationships between one British and several North American populations in Crepidula fornicata based on allozyme studies (Gastropoda: Calyptraeidae). J Molluscan Stud 51:177-182

Hoffmann RJ (1981a) Evolutionary genetics of Metridium senile. I. Kinetic differences in phosphoglucose isomerase allozymes. Biochem Genet 19:129-144

Hoffmann RJ (1981b) Evolutionary genetics of Metridium senile. II. Geographic patterns of allozyme variation. Biochem Genet 19:145-154

Holborn K, Johnson MS, Black R (1994) Population genetics of the corallivorous gastropod Drupella cornus at Ningaloo Reef, Western Australia. Coral Reefs 13:33-39

Holm ER, Bourget E (1994) Selection and population genetic structure of the barnacle Semibalanus balanoides in the northwest Atlantic and Gulf of St. Lawrence. Mar Ecol Prog Ser 113:247-256

Janson K, Ward RD (1984) Microgeographic variation in allozyme and shell characters in Littorina saxatilis Olivi (Prosobranchia: Littorinidae). Biol J Linn Soc 22:289-307

Johnson MW (1960) The offshore drift of larvae of the California spiny lobster Panulirus interruptus. Calif Coop Oceanic Fish Invest Rep 7:141-161

Johnson MW (1971a) On palinnurid and scyllarid lobster larvae and their distribution in the South China Sea (Decapoda: Palinuridae). Crustaceana 21:247-282

Johnson MW (1971b) The palinnurid and scyllarid lobster larvae of the tropical eastern Pacific and their distribution as related to the prevailing hydrography. Bull Scripps Inst Oceanogr 19:1-36

Johnson MS, Black R (1984) Pattern beneath the chaos: the effect of recruitment on genetic patchiness in an intertidal limpet. Evolution 38:1371-1383

Kendall MA, Bowman RS, Williamson P, Lewis JR (1982) Settlement patterns, density and stability in the barnacle Balanus balanoides. Neth J Sea Res 16:119-126

Ketchum BH (1954) Relation between circulation and planktonic populations in estuaries. Ecology 35:191-200

Knudsen JW (1960) Reproduction, life history and larval ecology of the Californian Xanthidae, the pebble crabs. Pac Sci 14:3-17

Lauzier LM (1965) Drift bottle observations in Northumberland strait, Gulf of St. Lawrence. J Fish Res Board Can 22: 353-368

Lauzier LM (1967) Bottom residual drift on the continental shelf area of the Canadian Atlantic coast. J Fish Res Board Can 24:1845-1859

Lavoie D (1995) Physical features of the Miramichi Estuary. In: Chadwick EMP (ed) Water, science and the public: the Miramichi ecosystem. Can Spec Publ Fish Aquat Sci 123:273-277

LeFèvre J, Bourget E (1991) Neustonic niche for cirripede larvae as a possible adaptation to long-range dispersal. Mar Ecol Prog Ser 74:185-194

LeFèvre J, Bourget E (1992) Hydrodynamics and behavior: transport processes in marine invertebrate larvae. Trends Ecol Evol 7:288-289

Locke A, Courtenay S (1996) Temperature, salinity and water clarity of the Miramichi Estuary, New Brunswick: a comparison of conditions in 1951 and 1992. Can Tech Rep Fish Aquat Sci 2137:1-23

Miron G, Boudreau B, Bourget E (1995) Use of larval supply in benthic ecology: testing correlations between larval supply and larval settlement. Mar Ecol Prog Ser 124:301-305

Editorial responsibility: Otto Kinne (Editor),

Oldendorf/Luhe, Germany
Mitton JB, Berg CJ, Orr KS (1989) Population structure, larval dispersal, and gene flow in the queen conch, Strombus gigas, of the Caribbean. Biol Bull 177:356-362

Nichols JH, Thompson BM, Cryer M (1982) Production, drift and mortality of the planktonic larvae of the edible crab (Cancer pagurus) off the north-east coast of England. Neth J Sea Res 16:173-184

Okubo A (1980) Diffusion and ecological problems: mathematical models. Springer-Verlag, Berlin, p 250

Omori M, Hamner WM (1982) Patchy distribution of zooplankton: behavior, population assessment and sampling problems. Mar Biol 72:193-200

Patarnello T, Battaglia B (1992) Glucosephosphate isomerase and fitness: Effects of temperature on genotype dependent mortality and enzyme activity in two species of the genus Gammarus (Crustacea: Amphipoda). Evolution 46: 1568-1573

Petrie B (1990) Monthly means of temperature, salinity and sigma-t for the Gulf of St. Lawrence. Can Tech Rep Hydrogr Ocean Sci 126

Possingham HP, Rougharden J (1990) Spatial population dynamics of a marine organism with a complex life cycle. Ecology 71:973-985

Pyefinch KA (1948) Methods of identification of the larvae of Balanus balanoides (L.), B. crenatus Brug. and Verruca stroemia O. F. Müller. J Mar Biol Assoc UK 27:451-463

Richards SA, Possingham HP, Noye BJ (1995) Larval dispersion along a straight coast with tidal currents: complex distribution patterns from a simple model. Mar Ecol Prog Ser 122:59-71

Roughgarden J, Gaines S, Possingham H (1988) Recruitment dynamics in complex life cycles. Science 241:1460-1466

Schmidt PS, Rand DM (1999) Intertidal microhabitat and selection at MPI: interlocus contrasts in the northern acorn barnacle, Semibalanus balanoides. Evolution 53:135-146

Shaklee JB, Allendorf FW, Morizot DC, Whitt GS (1990) Gene nomenclature for protein-coding loci in fish. Trans Am Fish Soc 119:2-15

Swofford DL, Selander RB (1989) BIOSYS-1. A computer program for the analysis of allelic variation in the population genetics and biochemical systematics (Release 1.7). Illinois Natural History Survey, Champaign, IL

Trites RW, Drinkwater KF (1991) The possible role of the surface circulation in the spread of PSP in the western Gulf of St. Lawrence in 1988. In: Therriault JC (ed) The Gulf of St. Lawrence: small ocean or big estuary? Can Spec Publ Fish Aquat Sci 113:153-160

Van Beneden RJ, Powers DA (1989) Structural and functional differentiation of two clinally distributed glucosephosphate isomerase allelic isozymes from the Teleost Fundulus heteroclitus. Mol Biol Evol 6:155-170

Van Guelpen L, Markle DF, Duggan DJ (1982) An evaluation of accuracy, precision, and speed of several zooplankton subsampling techniques. J Cons Int Explor Mer 40: 226-236

Wells HW, Wells MJ, Grey IE (1960) On the southern limits of Semibalanus balanoides (L.) in the Western Altantic. Ecology 11:587-590

Yoshioka PM (1986) Chaos and recruitment in the bryozoan Membranipora membranacea. Bull Mar Sci 39:408-417

Zamer WE, Hoffmann RJ (1989) Allozymes of glucose-6phosphate isomerase differentially modulate pentoseshunt metabolism in the sea anemone Metridium senile. Proc Natl Acad Sci USA 86:2737-2741

Submitted: September 11, 2000; Accepted: August 14, 2001

Proofs received from author(s): January 28, 2002 